\title{
EFEKTIVITAS PENGGUNAAN MEDIA LINGKUNGAN SEBAGAI SUMBER BELAJAR TERHADAP KEMAMPUAN SISWA MENULIS TEKS HASIL OBSERVASI DI SMA NEGERI 1 LIMBOTO BARAT
}

\author{
Hidrayana T., Salam, Muslimin \\ Magister Pendidikan Bahasa Indonesia, \\ Pascasarjana Universitas Negeri Gorontalo
}

\begin{abstract}
ABSTRAK
Tujuan penelitian adalah untuk: (1) mendeskripsikan pelaksanaan pembelajaran menulis teks laporan hasil observasi dengan menggunakan media lingkungan, (2) mendeskripsikan efektivitas penggunaan media lingkungan terhadap kemampuan siswa menulis teks laporan hasil observasi di SMA Negeri 1 Limboto Barat, dan (3) menguraikan secara komprehensif kemampuan siswa menulis teks laporan hasil observasi setelah menggunakan media lingkungan. Pendekatan yang digunakan adalah metode deskriptif kualitatif. Bentuk penelitian yakni quasi experimental design dengan jenis nonequivalent control group design. Data penelitian diperoleh melalui observasi (pengamatan), tes, wawancara, dan studi dokumentasi. Data penelitian dianalisis menggunakan SPSS untuk uji efektivitas. Hasil penelitian ini menunjukkan bahwa: (1) Pembelajaran menulis teks laporan hasil observasi pada siswa kelas $\mathrm{X}$ SMA Negeri 1 Limboto Barat terdiri atas tiga proses, yaitu (a) Perencanaan pembelajaran menulis teks laporan hasil observasi yang dirancang oleh guru telah memenuhi komponen penyusunan RPP yang sesuai dengan Kurikulum 2013, (b) Pelaksanaan pembelajaran yang terdiri atas kegiatan pendahuluan, kegiatan inti, dan kegiatan penutup, (c) Penilaian yang dilakukan oleh guru yaitu penilaian pengetahuan melalui tes dan penilaian keterampilan dari hasil menulis teks laporan hasil observasi; (2) Lingkungan sekolah sebagai sumber belajar dalam pembelajaran sudah efektif diterapkan dalam menulis teks laporan hasil observasi siswa kelas X SMA Negeri 1 Limboto Barat. Hal ini dibuktikan dari adanya perbedaan yang signifikan antara pengajaran menulis teks laporan hasil observasi menggunakan lingkungan sekolah sebagai sumber belajar dengan menggunakan media lingkungan; (3) Kemampuan menulis teks laporan hasil observasi berdasarkan pengamatan langsung siswa Kelas X SMA Negeri 1 Limboto Barat, diperoleh nilai rata-rata 75, yang berada pada kategori mampu. Kemampuan menulis teks laporan hasil observasi dengan menggunakan media lingkungan dari aspek isi siswa Kelas X SMA Negeri 1 Limboto Barat memperoleh nilai rata-rata 86 yang berada pada kategori sangat mampu.
\end{abstract}

Kata Kunci: Efektivitas, Media Lingkungan, Kemampuan, Menulis, Teks Laporan

\section{PENDAHULUAN}

Proses interaksi antara peserta didik dengan pendidik dan berbagai sumber belajar yang ada di lingkungan belajar disebut pembelajaran. Gagne, dkk. (dalam Warsita, 2008:266) menyatakan pembelajaran adalah suatu sistem yang bertujuan untuk membantu proses belajar peserta didik, yang berisi serangkaian peristiwa yang dirancang, disusun sedemikian rupa untuk mempengaruhi dan mendukung terjadinya proses belajar peserta didik yang bersifat internal. Warsita (2008:266) menjelaskan bahwa ada lima prinsip yang menjadi landasan pengertian pembelajaran yaitu: (1) pembelajaran sebagai usaha untuk memperoleh perubahan perilaku. Prinsip ini mengandung makna bahwa ciri utama proses pembelajaran itu adalah adanya perubahan perilaku dalam diri peserta didik; (2) hasil pembelajaran ditandai dengan perubahan perilaku secara keseluruhan. Prinsip ini mengandung makna bahwa perilaku sebagai hasil pembelajaran meliputi semua aspek perilaku dan bukan hanya satu atau dua aspek saja; (3) pembelajaran merupakan suatu proses. Prinsip ini mengandung makna bahwa pembelajaran itu merupakan suatu aktivitas yang berkesinambungan. Di dalam aktivitas in terjadi tahapan-tahapan belajar yang sistematis dan terarah, (4) proses pembelajaran terjadi karena adanya sesuatu yang mendorong dan 
adanya suatu tujuan yang akan dicapai, dan (5) pembelajaran merupakan bentuk pengalaman.

Berdasarkan pendapat tersebut, dapat disimpulkan bahwa pembelajaran adalah suatu usaha yang dilakukan oleh pendidik dalam membelajarkan peserta didik sehingga terjadi perubahan tingkah laku ke arah yang lebih baik. Oleh sebab itu, kegiatan pembelajaran yang dilaksanakan oleh guru, perlu dirancang secara khusus untuk memberikan pengalaman belajar pada siswa dengan melibatkan proses mental dan fisik melalui interaksi antar peserta didik, peserta didik dengan guru, lingkungan, dan sumber belajar lainnya dengan tujuan pencapaian kompetensi dasar.

Dalam proses pembelajaran berbahasa Indonesia, ada empat aspek keterampilan yang harus dikuasai oleh siswa, yaitu keterampilan menyimak, berbicara, membaca, dan menulis. Keempat aspek tersebut pada dasarnya merupakan satu kesatuan. Aspek-aspek ini adalah unsur-unsur dalam bahasa Indonesia yang tidak dapat dipisahkan karena satu dengan lainnya saling melengkapi. Hal ini membuktikan bahwa dalam pelaksanaan pembelajaran, sangat berkaitan antara aktivitas pembelajaran seorang guru dan siswa karena pada proses pembelajaran, guru dan siswa saling berinteraksi agar dapat mencapai kompetensi dasar yang telah ditetapkan. Dalam standar isi, pembelajaran bahasa dan sastra diarahkan untuk meningkatkan kemampuan siswa untuk berkomunikasi dalam bahasa Indonesia dengan baik dan benar, baik secara lisan maupun tertulis. Standar kompetensi bahasa dan sastra Indonesia juga dijadikan sebagai pengukur kemampuan minimal peserta didik yang menggambarkan penguasaan pengetahuan, keterampilan berbahasa, dan sikap positif terhadap bahasa dan sastra Indonesia. Oleh karena itu, pembelajaran bahasa dan sastra Indonesia diarahkan agar siswa terampil berkomunikasi, baik lisan maupun tulisan.

Kompetensi dasar (KD) jenjang SMA kelas $\mathrm{X}$ yang dijadikan objek penelitian ini adalah kompetensi dasar (KD) 3.2 Menelaah
Teks Laporan Hasil Observasi baik melalui lisan maupun tulisan dan KD 4.2 Menyajikan Teks Laporan Hasil Observasi baik secara lisan maupun tulis (Kemendikbud, 2017:12). Berdasarkan data yang telah diterima dapat dilihat di dalam RPP, perumusan indikator telah memiliki kesesuaian dengan SKL, KI, KD dan kesesuaian penggunaan kata kerja operasional dengan kompetensi yang diukur.

Sesuai dengan kompetensi dasar di atas, maka yang dimaksud dengan teks laporan hasil observasi adalah teks yang berisi hasil observasi dan analisis secara sistematis. Artinya, teks laporan hasil observasi menyajikan informasi tentang suatu hal secara apa adanya, kemudian dikelompokkan lalu dianalisis secara sistematis sehingga dapat menjelaskan suatu hal secara terperinci dari sudut pandang keilmuan. Laporan hasil observasi bisa berupa hasil riset secara mendalam mengenai suatu benda, tumbuhan, hewan, ekosistem, dan konsep-konsep ilmiah lainnya. Biasanya, teks laporan observasi bersisi fakta-fakta yang dapat dibuktikan secara ilmiah. Terkadang, fakta-fakta dari hasil observasi juga ditampilkan menggunakan gambar yang berupa tabel, grafik, atau bagan agar lebih menarik dan mudah dicermati.

Nurhanifah (2014) mengatakan bahwa teks laporan hasil observasi mempunyai ciriciri sebagai berikut: (1) harus mengandung fakta, (2) bersifat objektif, (3) harus ditulis sempurna dan lengkap, (4) tidak memasukkan hal-hal yang menyimpang, mengandung prasangka, atau pemihakan, dan (5) disajikan secara menarik, baik dalam hal tata bahasa yang jelas, isinya berbobot, maupun susunan logis.

Pada Kurikulum 2013 siswa diperkaya dengan keterampilan menulis beragam bentuk teks. Siswa dikenalkan dengan teks anekdot, teks eksplanasi, teks eksposisi, teks laporan hasil observasi, teks prosedur kompleks, dan teks negosiasi (Direktorat Pembinaan SMA, 2014:6). Akan tetapi dalam kenyataan di lapangan, kemampuan menulis siswa, khususnya SMA kelas sepuluh masih kurang memuaskan. 
Temuan awal peneliti berkaitan dengan masalah yang dihadapi siswa di sekolah dalam pembelajaran menulis di kelas X SMA Negeri 1 Limboto Barat dapat dijelaskan berikut: (1) Siswa masih kesulitan menuangkan ide-ide ke dalam bentuk tulisan. Masalah ini dapat diamati dari hasil tulisan siswa. Siswa pada saat diberi tugas menulis hanya mampu menulis dalam satu atau dua paragraf saja. Hal itu menunjukkan bahwa siswa masih memiliki kemampuan terbatas atau mengalami kesulitan dalam menuangkan ide-ide ke dalam bentuk tulisan, (2) Siswa belum memahami paragraf dengan utuh, sehingga isi atau informasi yang dikandung dalam suatu paragraf sulit dipahami. Sebuah paragraf yang ditulis siswa terdiri dari beberapa ide pokok sehingga tulisan sulit dipahami, (3) Isi dari sebuah tulisan tidak jelas. Hal ini terjadi karena dalam satu paragraf terdapat beberapa kalimat yang tidak koheren. Siswa kadang berpikir meloncat-loncat artinya pada awal paragraf menerangkan ide pokok tertentu, tetapi pada akhir paragraf tersebut dimasukkan pula ide pokok yang lain. Akibatnya pembaca sulit memahami isi tulisan yang dibacanya. (4) Diksi yang dimiliki siswa masih terbatas. Akibatnya tulisan menjadi kurang menarik dan menimbulkan kebosanan. (5) Masih banyak kesalahan dalam menerapkan aturan kebahasaan, misalnya penggunaan huruf besar, kata depan, atau tanda baca. (6) Siswa masih mengalami kesulitan dalam berpikir secara sistematis, sehingga informasi yang disampaikan berbelit-belit atau tumpang tindih. Salah satu ciri tulisan yang baik adalah tulisan itu mudah dipahami pembaca dengan cepat dan tepat. Hal itu akan terjadi jika tulisan disampaikan dengan sistematis, (7) Pernyataan cenderung menyebar atau tidak terfokus. Pemborosan kalimat sering terjadi, hal ini karena siswa mengulang isi kalimat tetapi tidak mendukung ide pokok yang sedang dijelaskan.

Dari masalah-masalah di atas yang berkaitan dengan penelitian ini yaitu isi, sistematika, kosakata, dan kebahasaan. Keempat unsur di atas dapat diamati dari hasil tulisan siswa. Oleh karena itu, unsur-unsur di atas akan menjadi fokus penelitian ini.

Menulis merupakan suatu kegiatan komunikasi untuk menyampaikan pesan (informasi) secara tertulis kepada pihak lain dengan menggunakan bahasa tulis sebagai medianya. Menulis juga sangat penting bagi siswa untuk dapat mengembangkan daya berpikir kritis siswa terhadap suatu persoalan yang sedang hangat-hangatnya diperbincangkan dan diungkapkannya dalam aktivitas menulis. Wawasan siswa juga dapat bertambah seiring aktivitas menulis yang terus dilakukan. Daya kreativitas siswa akan terus berkembang sebab menulis merupakan proses kreatif. Dengan menulis seseorang dapat mengungkapkan sesuatu yang seseorang tidak mampu mengungkapkannya secara lisan, atau tidak mempunyai keberanian dalam mengungkapkannya secara lisan.

Menurut Semi (2007:14), tujuan menulis adalah sebagai berikut. (1) Untuk menceritakan sesuatu. Menceritakan sesuatu kepada orang lain mem-punyai maksud agar orang lain atau pembaca tahu tentang apa yang dialami yang bersangkutan. Pembaca tahu apa yang diimpikan, dikhayalkan dan dipikirkan penulis.

Berkaitan dengan pendapat di atas, penulis lebih mengarahkan pada menulis teks laporan hasil observasi. Teks laporan observasi adalah teks yang berfungsi untuk mendeskripsikan atau mengklasifikasikan informasi. Laporan tersebut menginformasikan sesuatu yang hidup seperti tumbuhan dan hewan atau suatu kejadian benda mati seperti kendaraan atau laut (Kemendikbud, 2013:2).

Menulis teks laporan hasil observasi (observation report) menurut Anderson (dalam Wijanarko, 2014:15) ialah pernyataan umum sebagai pembuka yang memperkenalkan hal yang akan dibahas. Itu dapat berisi deskripsi pendek dan definisi. Sekumpulan paragraf tentang hal yang dibahas, biasanya di setiap paragraf baru menggolongkan ciri tentang hal yang dibahas dan dimulai dengan kalimat utama. Rangkuman dari informasi yang 
disajikan dan tanda berakhirnya teks laporan ini.

Berdasarkan uraian di atas penulis dapat menyimpulkan bahwa menulis laporan hasil observasi adalah laporan dalam bentuk tertulis yang dilakukan oleh siswa terhadap pengamatan suatu objek yang dapat dilihat oleh mereka sehingga dapat didata dan validitas datanya bisa dibuktikan secara nyata di muka umum serta ruang lingkup yang diteliti atau diamati pun harus benar-benar pasti tidak boleh berubah-ubah untuk menentukan keberhasilan dari observasi tersebut.

Salah satu upaya untuk membantu mengatasi rendahnya minat menulis siswa, khususnya menulis teks laporan hasil observasi dengan cara mengoptimalkan penggunaan media dalam proses belajar-mengajar. Media yang diasumsikan tepat untuk mengatasi permasalahan rendahnya kemampuan siswa menulis teks laporan hasil observasi di SMA Negeri 1 Limboto Barat adalah dengan menggunakan media lingkungan. Media lingkungan adalah segala sesuatu baik yang berupa benda hidup maupun benda mati yang terdapat di sekitar kita (di sekitar tempat tinggal maupun sekolah). Guru dapat memilih dan memanfaatkan berbagai benda yang terdapat di lingkungan untuk dijadikan sebagai media sekaligus sebagai sumber belajar bagi siswa di sekolah. Bentuk dan jenis lingkungan ini bermacam macam, misalnya: sawah, hutan, pabrik, lahan pertanian, gunung, danau, sungai peninggalan sejarah, museum, dan sebagainya. Media di lingkungan juga bisa berupa benda-benda sederhana yang dapat dibawa ke ruang kelas, misalnya: batuan, tumbuh-tumbuhan, binatang, peralatan rumah tangga, hasil kerajinan, dan masih banyak lagi contoh yang lain. Semua benda itu dapat dikumpulkan dan digunakan sebagai media pembelajaran di kelas. Jika memungkinkan, guru dapat menugaskan para siswa untuk mengumpulkan benda-benda tertentu sebagai sumber belajar untuk topik tertentu.

Penggunaan media lingkungan, sangat tepat jika dikaitkan dengan pembelajaran menulis teks laporan hasil observasi. Hal itu disebabkan karena aspek latar atau tempat pada lingkungan sekitar memenuhi prinsip dalam menulis teks laporan hasil observasi. Dengan mengacu pada uraian di atas, maka pembelajaran menulis teks laporan hasil observasi dengan menggunakan media lingkungan diharapkan dapat mendorong siswa agar mampu menulis berdasarkan gagasan yang dimiliki.

Tujuan penelitian yang ingin dicapai, yaitu (1) mendeskripsikan pelaksanaan pembelajaran menulis teks laporan hasil observasi dengan menggunakan media lingkungan sebagai sumber belajar di SMA Negeri 1 Limboto Barat, (2) mendeskripsikan efektivitas penggunaan media lingkungan sebagai sumber belajar terhadap kemampuan siswa menulis teks laporan hasil observasi di SMA Negeri 1 Limboto Barat, dan (3) menguraikan secara komprehensif kemampuan siswa menulis teks laporan hasil observasi setelah menggunakan media lingkungan sebagai sumber belajar.

\section{METODE PENELITIAN}

Pendekatan penelitian yang digunakan dalam penelitian ini adalah pendekatan deskriptif kualitatif. Pendekatan deskriptif kualitatif merupakan prosedur penelitian yang menghasilkan data deskriptif verbal yang secara konkret terwujud melalui kata-kata sebagai deskripsi tentang pembelajaran menulis teks laporan hasil observasi pada siswa Kelas X SMA Negeri 1 Limboto Barat. Bentuk penelitian yang digunakan dalam penelitian ini adalah quasi experimental design dengan jenis nonequivalent control group design. Pada desain ini, kelompok eksperimen maupun kelompok kontrol tidak dipilih secara acak.

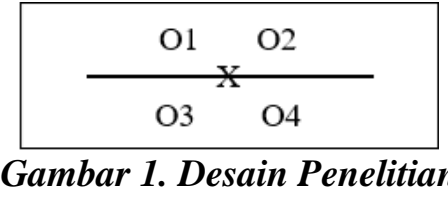

$\mathrm{O} 1=$ Kelompok eksperimen sebelum perlakuan

$\mathrm{O} 3=$ Kelompok kontrol sebelum perlakuan 
$\mathrm{X}=$ Perlakuan

$\mathrm{O} 2=$ Kelompok eksperimen setelah perlakuan

$\mathrm{O} 4=$ Kelompok kontrol yang diberi perlakuan lain

Sumber data penelitian ini berupa sumber data tertulis dan sumber data aktivitas proses belajar mengajar yang terjadi di lapangan. Sumber data tertulis meliputi RPP, silabus, catatan lapangan, observasi kegiatan guru dan siswa, hasil wawancara dari narasumber yaitu guru dan siswa, instrumen penilaian kinerja guru oleh siswa, kuesioner, dokumentasi serta hasil tulisan siswa yang digunakan sebagai evaluasi pembelajaran. Prosedur penelitian terdiri dari beberapa tahap, yaitu menentukan masalah penelitian, pengumpulan data, dan analisis dan penyajian data.

\section{HASIL DAN PEMBAHASAN}

A. Deskripsi Pelaksanaan Pembelajaran Menulis Teks Laporan Hasil Observasi dengan Menggunakan Media Lingkungan di SMA Negeri 1 Limboto Barat

Langkah awal dalam proses pembelajaran menulis Teks Laporan Hasil Observasi dengan menggunakan media lingkungan di SMA Negeri 1 Limboto Barat adalah merencanakan pembelajaran. Hal tersebut bertujuan untuk mengoptimalkan proses pembelajaran. Rencana pembelajaran yang digunakan oleh guru yang mengajar di SMA Negeri 1 Limboto Barat tertuang dalam rancangan perencanaan pembelajaran (RPP). Komponen-komponen yang terdapat dalam RPP meliputi identitas mata pelajaran (terdapat satuan pendidikan, mata pelajaran, kelas/semester, materi pokok, alokasi waktu), kompetensi inti dan kompetensi dasar, indikator pencapaian kompetensi, tujuan pembelajaran, materi pembelajaran, pendekatan dan model pembelajaran, media atau sumber pembelajaran (meliputi kegiatan pendahuluan, kegiatan inti, dan kegiatan penutup), dan penilaian pembelajaran.
B. Deskripsi Efektivitas Penggunaan Media Lingkungan terhadap Kemampuan Siswa Menulis Teks Laporan Hasil Observasi di SMA Negeri 1 Limboto Barat

1. Data analisis pre-test (tes awal) kemampuan kelas kontrol

Data menunjukkan bahwa tidak ada siswa yang mampu memperoleh skor 100 sebagai skor maksimal. Skor tertinggi yang dicapai oleh siswa adalah 83 yang diperoleh oleh 1 orang dan skor terendah yang diperoleh siswa adalah 61 yang dicapai oleh 1 orang. Klasifikasi kemampuan menulis teks laporan hasil observasi siswa kelas X SMA Negeri 1 Limboto Barat yang dideskripsikan berdasarkan kategori nilai dapat diamati pada Tabel 1.

Tabel 1. Klasifikasi Nilai Pre-test Menulis Teks Laporan Hasil Observasi Siswa Kelas X SMA Negeri 1 Limboto Barat pada Kelas Kontrol

\begin{tabular}{|c|c|c|c|c|}
\hline No & $\begin{array}{c}\text { Nilai } \\
(\mathbf{P})\end{array}$ & $\begin{array}{c}\text { Frekuen } \\
\text { si (f) }\end{array}$ & $\begin{array}{c}\text { Persenta } \\
\text { se } \mathbf{( \% )}\end{array}$ & $\begin{array}{c}\text { Katego } \\
\text { ri }\end{array}$ \\
\hline 1 & $\geq 90$ & 0 & 0 & $\begin{array}{c}\text { Sangat } \\
\text { tinggi }\end{array}$ \\
\hline 2 & $75-89$ & 8 & 21,62 & Tinggi \\
\hline 3 & $60-74$ & 29 & 78,37 & Sedang \\
\hline 4 & $45-59$ & 0 & 0 & Rendah \\
\hline 5 & $<45$ & 0 & 0 & $\begin{array}{c}\text { Sangat } \\
\text { rendah }\end{array}$ \\
\hline \multicolumn{2}{|c|}{ Jumlah } & $\mathbf{3 7}$ & $\mathbf{1 0 0}$ & \\
\hline
\end{tabular}

Adaptasi dari Nurgiyantoro (2001:399)

Data pada Tabel 1 menunjukkan bahwa siswa yang memperoleh nilai pada kategori tinggi adalah sebanyak 8 orang $(21,62 \%)$, sedangkan siswa yang memperoleh nilai pada kategori sedang adalah sebanyak 29 orang $(78,37 \%)$. Hal ini menunjukkan bahwa tingkat kemampuan pre-test siswa kelas kontrol dalam menulis teks laporan hasil observasi dengan menggunakan media konvensional dikategorikan sedang. Nilai perolehan siswa pada pre-test yang dikonfirmasikan terhadap nilai KKM Bahasa Indonesia dapat dikonversikan ke dalam klasifikasi 
tingkat kemampuan siswa dan dijabarkan dalam Tabel 2.

Tabel 2. Klasifikasi Tingkat Kemampuan Menulis Teks Laporan Hasil Observasi Siswa Kelas X SMA Negeri 1 Limboto Barat pada Pre-test Kelas Kontrol

\begin{tabular}{|c|c|c|c|}
\hline Nilai & Frekuensi & $\begin{array}{c}\text { Persentase } \\
(\%)\end{array}$ & Kategori \\
\hline$\geq 75$ & 8 & 21,62 & Tuntas \\
\hline$<75$ & 29 & 78,37 & $\begin{array}{l}\text { Tidak } \\
\text { Tuntas }\end{array}$ \\
\hline Jumlah & 37 & 100 & \\
\hline
\end{tabular}

dinyatakan bahwa tingkat keterampilan menulis teks laporan hasil observasi siswa kelas X SMA Negeri 1 Limboto Barat belum memadai karena sebagian besar siswa masih berada di bawah nilai KKM yang telah ditetapkan. Hal ini ditunjukkan dengan siswa yang memperoleh nilai 75-89 hanya berjumlah 8 orang $(21,62 \%)$ dan siswa yang memperoleh nilai kurang dari 75 adalah sebanyak 29 orang (75\%). Siswa dikatakan mampu apabila ada $85 \%$ siswa yang memperoleh nilai 75-100.

2. Data analisis post-test (tes akhir) kemampuan kelas kontrol

Data analisis post-test dengan 36 orang siswa yang dianalisis memperoleh gambaran bahwa tidak ada siswa yang mampu memperoleh skor 100 sebagai skor maksimal. Skor tertinggi yang dicapai oleh siswa adalah 90 yang hanya dicapai oleh 1 orang $(2,7 \%)$ dan skor terendah yang diperoleh oleh siswa adalah 72 yang dicapai oleh 2 orang $(5,4 \%)$. Klasifikasi kemampuan menulis teks laporan hasil observasi siswa kelas X SMA Negeri 1 Limboto Barat yang dideskripsikan berdasarkan kategori nilai dapat diamati pada Tabel 3.

Tabel 3. Klasifikasi Kemampuan Menulis Teks Laporan Hasil Observasi Siswa Kelas X SMA Negeri 1 Limboto

\begin{tabular}{|c|c|c|c|c|}
\hline No. & $\begin{array}{c}\text { Nilai } \\
(\mathbf{P})\end{array}$ & $\begin{array}{c}\text { Frekuensi } \\
(\mathbf{f})\end{array}$ & $\begin{array}{c}\text { Persentase } \\
(\boldsymbol{\%})\end{array}$ & $\begin{array}{c}\text { Tingkat } \\
\text { Penguasaan }\end{array}$ \\
\hline 1 & $\geq 90$ & 1 & 2,7 & $\begin{array}{c}\text { Sangat } \\
\text { tinggi }\end{array}$ \\
\hline 2 & $75-89$ & 22 & 59,46 & Tinggi \\
\hline
\end{tabular}

\begin{tabular}{|c|c|c|c|c|}
\hline 3 & $60-74$ & 14 & 37,84 & Sedang \\
\hline 4 & $45-59$ & 0 & 0 & Rendah \\
\hline 5 & $<45$ & 0 & 0 & $\begin{array}{c}\text { Sangat } \\
\text { rendah }\end{array}$ \\
\hline \multicolumn{2}{|c|}{ Jumlah } & $\mathbf{3 7}$ & $\mathbf{1 0 0}$ & \\
\hline
\end{tabular}

Adaptasi dari Nurgiyantoro (2001:399)

Data pada Tabel 3 menunjukkan bahwa hanya ada 1 orang siswa yang memperoleh nilai pada kategori sangat tinggi $(2,7 \%)$, siswa yang memperoleh nilai pada kategori tinggi berjumlah 22 orang $(59,46 \%)$, sedangkan siswa yang memperoleh nilai pada kategori sedang berjumlah 14 orang $(37,84 \%)$. Hal ini menunjukkan bahwa tingkat kemampuan post-test siswa kelas kontrol dalam menulis teks laporan hasil observasi dengan menggunakan media konvensional dikategorikan sedang. Nilai tersebut dikonfirmasikan ke dalam kriteria ketuntasan yang telah ditetapkan oleh pihak sekolah untuk mata pelajaran bahasa Indonesia. Kriteria Ketuntasan Minimal (KKM) yang telah ditetapkan oleh pihak sekolah untuk mata pelajaran bahasa Indonesia yaitu 75. Klasifikasi tingkat kemampuan siswa dapat dilihat pada Tabel 4.

Tabel 4. Klasifikasi Tingkat Kemampuan Menulis Teks Laporan Hasil Observasi Siswa Kelas X SMA Negeri 1 Limboto Barat pada Post-test Kelas Kontrol

\begin{tabular}{|c|c|c|c|}
\hline Nilai & Frekuensi & $\begin{array}{c}\text { Persentase } \\
(\%)\end{array}$ & Kategori \\
\hline$\geq 75$ & 23 & 62,16 & Tuntas \\
\hline$<75$ & 14 & $37,84 \%$ & $\begin{array}{l}\text { Tidak } \\
\text { Tuntas }\end{array}$ \\
\hline Jumlah & 37 & 100 & \\
\hline
\end{tabular}

dinyatakan bahwa tingkat keterampilan menulis teks laporan hasil observasi siswa kelas X SMA Negeri 1 Limboto Barat, untuk kelompok kontrol, belum memadai. Hal ini ditunjukkan dengan jumlah siswa yang memperoleh nilai $\geq 75$ hanya berjumlah 23 orang $(62,16 \%)$. Siswa dikatakan mampu apabila ada $85 \%$ siswa yang memperoleh nilai 75-100. 
3. Data analisis pre-test (tes awal) kemampuan kelas eksperimen

Hasil analisis pre-test dengan 36 orang siswa yang dianalisis memperoleh gambaran bahwa skor tertinggi yang dicapai oleh siswa adalah 83 yang hanya dicapai oleh 1 orang $(2,7 \%)$ dan skor terendah yang diperoleh oleh siswa adalah 60 yang dicapai oleh 1 orang $(2,7 \%)$. Klasifikasi kemampuan menulis teks laporan hasil observasi siswa kelas X SMA Negeri 1 Limboto Barat yang dideskripsikan berdasarkan kategori nilai dapat diamati pada Tabel 5.

Tabel 5. Klasifikasi Nilai Pre-test Menulis Teks Laporan Hasil Observasi Siswa Kelas X SMA Negeri 1 Limboto Barat pada Kelas Eksperimen

\begin{tabular}{|c|c|c|c|c|}
\hline No & $\begin{array}{c}\text { Nilai } \\
\text { (P) }\end{array}$ & $\begin{array}{l}\text { Frekuen } \\
\text { si (f) }\end{array}$ & $\begin{array}{c}\text { Persenta } \\
\text { se }(\%)\end{array}$ & $\begin{array}{c}\text { Katego } \\
\text { ri }\end{array}$ \\
\hline 1 & $\geq 90$ & 0 & 0 & $\begin{array}{l}\text { Sangat } \\
\text { tinggi }\end{array}$ \\
\hline 2 & $75-89$ & 10 & 27,78 & Tinggi \\
\hline 3 & 60-74 & 26 & 72,22 & Sedang \\
\hline 4 & $45-59$ & 0 & 0 & Rendah \\
\hline 5 & $<45$ & 0 & 0 & $\begin{array}{l}\text { Sangat } \\
\text { rendah }\end{array}$ \\
\hline \multicolumn{2}{|c|}{ Jumlah } & 36 & 100 & \\
\hline
\end{tabular}
Adaptasi dari Nurgiyantoro (2001:399)

Data pada Tabel 5 menunjukkan bahwa siswa yang memperoleh nilai pada kategori tinggi adalah sebanyak 10 orang $(27,78 \%)$, sedangkan siswa yang memperoleh nilai pada kategori sedang adalah sebanyak 26 orang $(72,22 \%)$. Hal ini menunjukkan bahwa tingkat kemampuan pre-test siswa kelas eksperimen dalam menulis teks laporan hasil observasi dengan menggunakan media konvensional dikategorikan sedang. Nilai perolehan siswa pada pre-test yang dikonfirmasikan terhadap nilai KKM Bahasa Indonesia dapat dikonversikan ke dalam klasifikasi tingkat kemampuan siswa dan dijabarkan dalam Tabel 6.

Tabel 6. Klasifikasi Tingkat Kemampuan Menulis Teks Laporan Hasil Observasi Siswa Kelas X SMA Negeri 1 Limboto Barat pada Pre-test Kelas Eksperimen

\begin{tabular}{|c|c|c|c|}
\hline Nilai & Frekuensi & $\begin{array}{c}\text { Persentase } \\
(\mathbf{\%})\end{array}$ & Kategori \\
\hline$\geq 75$ & 10 & 27,78 & Tuntas \\
\hline$<75$ & 26 & 72,22 & $\begin{array}{c}\text { Tidak } \\
\text { Tuntas }\end{array}$ \\
\hline Jumlah & $\mathbf{3 6}$ & $\mathbf{1 0 0}$ & \\
\hline \multicolumn{3}{|c}{ Berdasarkan } & Tabel 6 dapat
\end{tabular}

dinyatakan bahwa tingkat keterampilan menulis teks laporan hasil observasi siswa kelas X SMA Negeri 1 Limboto Barat belum memadai karena sebagian besar siswa masih berada di bawah nilai KKM yang telah ditetapkan. Hal ini ditunjukkan dengan siswa yang memperoleh nilai $\geq 75$ hanya berjumlah 10 orang $(27,78 \%)$ dan siswa yang memperoleh nilai kurang dari 75 adalah sebanyak 26 orang (72,22\%). Siswa dikatakan mampu apabila ada $85 \%$ siswa yang memperoleh nilai 75-100.

4. Data analisis post-test (tes akhir) kemampuan kelas eksperimen

Hasil analisis data post-test kelas eksperimen yang berjumlah 36 orang siswa memperoleh gambaran bahwa tidak ada siswa yang mampu memperoleh skor 100 sebagai skor maksimal. Skor tertinggi yang dicapai oleh siswa adalah 93 yang dicapai oleh 1 orang $(2,7 \%)$ dan skor terendah yang diperoleh oleh siswa adalah 69 yang dicapai oleh 1 orang $(2,7 \%)$. Klasifikasi kemampuan menulis teks laporan hasil observasi siswa kelas X SMA Negeri 1 Limboto Barat yang dideskripsikan berdasarkan kategori nilai dapat diamati pada Tabel 7.

Tabel 7. Klasifikasi Nilai Post-test Menulis Teks Laporan Hasil Observasi Siswa Kelas X SMA Negeri 1 Limboto Barat pada Kelas Kontrol

\begin{tabular}{|c|c|c|c|c|}
\hline $\mathbf{N}$ & $\begin{array}{c}\text { Kemamp } \\
\text { uan (P) }\end{array}$ & $\begin{array}{c}\text { Frekue } \\
\text { nsi }\end{array}$ & $\begin{array}{c}\text { Persent } \\
\text { ase (\%) }\end{array}$ & $\begin{array}{c}\text { Tingkat } \\
\text { Penguas } \\
\text { aan }\end{array}$ \\
\hline 1 & $\geq 90$ & 8 & 22,22 & $\begin{array}{c}\text { Sangat } \\
\text { Tinggi }\end{array}$ \\
\hline 2 & $75-89$ & 24 & 66,7 & Tinggi \\
\hline 3 & $60-74$ & 4 & 11,11 & Sedang \\
\hline 4 & $45-59$ & 0 & 0 & Rendah \\
\hline 5 & $<45$ & 0 & 0 & $\begin{array}{c}\text { Sangat } \\
\text { Rendah }\end{array}$ \\
\hline \multicolumn{2}{|c|}{ Jumlah } & $\mathbf{3 6}$ & $\mathbf{1 0 0}$ & \\
\hline
\end{tabular}


Adaptasi dari Nurgiyantoro (2001:399)

Data pada Tabel 7 menunjukkan bahwa hanya ada 8 orang siswa $(22,22 \%)$ yang memperoleh nilai pada kategori sangat tinggi, siswa yang memperoleh nilai pada kategori tinggi berjumlah 24 orang $(66,7 \%)$, sedangkan siswa yang memperoleh nilai pada kategori sedang berjumlah 4 orang $(11,11 \%)$. Hal ini menunjukkan bahwa tingkat kemampuan post-test siswa kelas kontrol dalam menulis teks laporan hasil observasi dengan menggunakan media konvensional dikategorikan tinggi. Nilai tersebut dikonfirmasikan ke dalam kriteria ketuntasan yang telah ditetapkan oleh pihak sekolah untuk mata pelajaran bahasa Indonesia. Kriteria Ketuntasan Minimal (KKM) yang telah ditetapkan oleh pihak sekolah untuk mata pelajaran bahasa Indonesia yaitu 75. Klasifikasi tingkat kemampuan siswa dapat dilihat pada Tabel 8.

Tabel 8. Klasifikasi Tingkat Kemampuan Menulis Teks Laporan Hasil Observasi Siswa Kelas X SMA Negeri 1 Limboto Barat pada Post-test Kelas Eksperimen

\begin{tabular}{|c|c|c|c|}
\hline $\begin{array}{c}\text { Kemampua } \\
\mathbf{n}(\mathbf{P})\end{array}$ & $\begin{array}{c}\text { Frekuen } \\
\text { si }\end{array}$ & $\begin{array}{c}\text { Persentas } \\
\text { e }(\%)\end{array}$ & $\begin{array}{r}\text { Katego } \\
\text { ri }\end{array}$ \\
\hline$\geq 75$ & 32 & $88,89 \%$ & Tuntas \\
\hline$<75$ & 4 & $11,11 \%$ & $\begin{array}{c}\text { Tidak } \\
\text { Tuntas }\end{array}$ \\
\hline Jumlah & 36 & $100 \%$ & \\
\hline
\end{tabular}
dinyatakan bahwa tingkat keterampilan menulis teks laporan hasil observasi siswa kelas X SMA Negeri 1 Limboto Barat, untuk kelompok eksperimen, sudah memadai. Hal ini ditunjukkan dengan jumlah siswa yang memperoleh nilai $\geq 75$ berjumlah 30 orang $(88,89 \%)$ dan yang mendapat nilai 0-75 sebanyak 4 orang $(11,11)$. Siswa dikatakan mampu apabila ada $85 \%$ siswa yang memperoleh nilai 75 100.

\section{Keefektifan lingkungan sekolah sebagai sumber belajar}

Berdasarkan hasil analisis data tes kelas kontrol dan kelas eksperimen dapat diketahui keefektifan penggunaan lingkungan sekolah sebagai sumber belajar dalam pengajaran menulis teks laporan hasil observasi siswa kelas X SMA Negeri 1 Limboto Barat. Untuk menganalisis keefektifan penggunaan lingkungan sekolah sebagai sumber belajar digunakan teknik analisis statistik inferensial atau uji t. Hasil analisis statistika inferensial dimaksudkan untuk menjawab hipotesis penelitian yang telah dirumuskan sebelumnya. Sebelum melakukan analisis inferensial terlebih dahulu dilakukan beberapa pengujian persyaratan analisis, yaitu uji normalitas dan uji homogenitas. Hal ini dilakukan untuk mengetahui apakah data yang diperoleh dari hasil penelitian berdistribusi normal dan homogen. Selanjutnya, barulah dapat diadakan uji hipotesis untuk mengetahui data yang diperoleh dari hasil penelitian (kelas kontrol dan kelas eksperimen).

\section{Uraian Secara Komprehensif Kemampuan Siswa Menulis Teks Laporan Hasil Observasi Setelah Menggunakan Media Lingkungan}

Nilai siswa dalam menulis Teks Laporan Hasil Observasi, terlihat bahwa dari 32 jumlah siswa sampel, nilai 25 dengan frekuensi 1 orang dan persentase $(3,2 \%)$. Nilai 50 dengan frekuensi 1 orang dan persentase $(3,2 \%)$. Nilai 54 dengan frekuensi 1 orang dan persentase $(3,2 \%)$. Nilai 58 dengan frekuensi 4 orang dan persentase $(12,5 \%)$. Nilai 67 dengan frekuensi 2 orang dan persentase $(6,2 \%)$. Nilai 71 dengan frekuensi 3 orang dan persentase $(9,4 \%)$. Nilai 75 dengan frekuensi 2 orang dan persentase $(6,2 \%)$. Nilai 79 dengan frekuensi 7 orang dan persentase $(21,8 \%)$. Nilai 83 dengan frekuensi 1 orang dan persentase $(3,2 \%)$. Nilai 88 dengan frekuensi 6 orang dan persentase $(18,7 \%)$. Nilai 92 dengan frekuensi 2 orang dan persentase $(6,2 \%)$, 
dan nilai 96 dengan frekuensi 2 orang dan persentase $(6,2 \%)$. Klasifikasi kemampuan siswa menulis teks laporan hasil observasi menggunakan media lingkungan dapat dilihat pada Tabel 9.

Tabel 9. Klasifikasi Kemampuan Siswa Menulis Teks Laporan Hasil Observasi Menggunakan Media Lingkungan

\begin{tabular}{|c|c|c|c|c|}
\hline $\begin{array}{c}\text { N } \\
\text { o. }\end{array}$ & $\begin{array}{c}\text { Kemamp } \\
\text { uan (P) }\end{array}$ & $\begin{array}{c}\text { Frekue } \\
\text { nsi }\end{array}$ & $\begin{array}{c}\text { Persent } \\
\text { ase (\%) }\end{array}$ & $\begin{array}{c}\text { Tingkat } \\
\text { Penguas } \\
\text { aan }\end{array}$ \\
\hline 1. & $85-100$ & 10 & 31,25 & $\begin{array}{c}\text { Sangat } \\
\text { mampu }\end{array}$ \\
\hline 2. & $75-84$ & 10 & 31,25 & Mampu \\
\hline 3. & $55-74$ & 9 & 28,1 & $\begin{array}{c}\text { Cukup } \\
\text { mampu }\end{array}$ \\
\hline 4. & $24-54$ & 3 & 9,4 & $\begin{array}{c}\text { Kurang } \\
\text { mampu }\end{array}$ \\
\hline \multicolumn{2}{|c|}{ Jumlah } & $\mathbf{3 2}$ & $\mathbf{1 0 0}$ & \\
\hline
\end{tabular}

Dengan demikian siswa Kelas $\mathrm{X}$ SMA Negeri 1 Limboto Barat dalam menulis teks laporan hasil observasi menggunakan media lingkungan sudah tergolong baik karena sebanyak 62,5\% siswa telah mencapai Kriteria Ketuntasan Minimal (KKM) yang diterapkan di SMA Negeri 1 Limboto Barat yaitu 75. Dengan ketentuan apabila jumlah siswa mencapai $85 \%$ yang memperoleh nilai $75-100$.

\section{SIMPULAN}

1. Pelaksanaan Pembelajaran Menulis Teks laporan hasil observasi dengan Menggunakan Media Lingkungan di SMA Negeri 1 Limboto Barat

Berdasarkan hasil penelitian yang dilaksanakan di SMA Negeri 1 Limboto Barat tahun pelajaran 2019/2020 dapat disimpulkan bahwa pembelajaran menulis teks laporan hasil observasi pada siswa kelas X SMA Negeri 1 Limboto Barat terdiri atas tiga proses sebagai berikut. (1) Perencanaan pembelajaran menulis teks laporan hasil observasi yang dirancang oleh guru telah memenuhi komponen penyusunan RPP (Rencana Pelaksanaan Pembelajaran) yang sesuai dengan Kurikulum 2013, (2) Pelaksanaan pembelajaran terdiri atas kegiatan pendahuluan, kegiatan inti, dan kegiatan penutup. Tidak hanya itu, guru pun memberikan arahan atau tidak lanjut kegiatan pembelajaran pada akhir-akhir penutupan pertemuan pembelajaran, (3) Penilaian yang dilakukan oleh guru yaitu dengan penilaian pengetahuan yang dinilai guru yaitu dengan tanya jawab yang dilakukan dengan siswa dan penilaian keterampilan yang dinilai guru dari hasil menulis teks laporan hasil observasi.

\section{Efektivitas Penggunaan Media Lingkungan terhadap Kemampuan Siswa Menulis Teks laporan hasil observasi di SMA Negeri 1 Limboto Barat \\ Berdasarkan hasil analisis data dan} pembahasan dapat ditarik kesimpulan yang terkait dengan penelitian ini sebagai berikut: (1) Kemampuan menulis teks laporan hasil observasi dengan menggunakan media lingkungan siswa kelas X SMA Negeri 1 Limboto Barat berdasarkan hasil pengujian yang dilakukan dengan menggunakan teknik analisis statistik deskriptif pada kelas kontrol menunjukkan bahwa hasil pembelajaran yang dicapai siswa yang memperoleh nilai memenuhi KKM hanya 23 orang atau $62,16 \%$ dan yang belum mencapai KKM sebanyak 14 orang atau $37,84 \%$. Dengan perolehan nilai rata-rata 78,57 berada pada kategori tinggi, (2) Kemampuan menulis teks laporan hasil observasi dengan menggunakan lingkungan sekolah sebagai sumber belajar pada siswa kelas X SMA Negeri 1 Limboto Barat berdasarkan hasil pengujian yang dilakukan dengan menggunakan teknik analisis statistik deskriptif pada kelas eksperimen menunjukkan bahwa hasil pembelajaran yang dicapai siswa yang memperoleh nilai memenuhi KKM sebanyak 32 orang siswa atau $88,89 \%$ dan yang belum mampu memenuhi nilai KKM hanya 4 orang atau $11,11 \%$. Dengan perolehan nilai rata-rata 81,17 berada pada kategori tinggi, dan (3) Lingkungan sekolah sebagai sumber belajar dalam pembelajaran efektif diterapkan dalam menulis teks laporan hasil observasi siswa kelas $X$ SMA Negeri 1 Limboto Barat. Hal ini dibuktikan dari adanya perbedaan yang signifikan antara pengajaran menulis teks 
laporan hasil observasi menggunakan lingkungan sekolah sebagai sumber belajar dengan menggunakan media lingkungan. Perbandingan hasil kemampuan kelas eksperimen dan kelas kontrol tampak dari hasil uji $\mathrm{t}$ (hipotesis) menggunakan uji inferensial jenis uji-t independent sample test dan diperoleh nilai $t$ sebesar 2,961 dengan signifikan $p=0,574$, nilai $\mathrm{p}>0,05$ atau 0,574 $>0,05$ maka hipotesis nol (H0) ditolak dan hipotesis aklternatif (H1) diterima.

\section{Kemampuan Siswa Menulis Teks laporan hasil observasi Setelah Menggunakan Media Lingkungan}

Kemampuan menulis teks laporan hasil observasi berdasarkan pengamatan langsung siswa Kelas X SMA Negeri 1 Limboto Barat, diperoleh nilai rata-rata 75 , yang berada pada kategori kemampuan yakni mampu. Kemampuan menulis teks laporan hasil observasi dengan menggunakan media lingkungan dari aspek isi siswa Kelas X SMA Negeri 1 Limboto Barat memperoleh nilai ratarata 86 yang berada pada kategori sangat mampu. Hal ini menunjukkan tulisan siswa sudah mampu menyesuaikan isi tulisan dengan judul, menyesuaikan isi tulisan dengan objek, dan menciptakan kesan indra terhadap pembaca. Kemampuan menulis teks laporan hasil observasi berdasarkan pengamatan langsung dari aspek struktur siswa Kelas $\mathrm{X}$ SMA Negeri 1 Limboto Barat memperoleh nilai rata-rata 77 yang berada pada kategori mampu. Hal ini dikarenakan sebagian besar siswa sudah mampu memunculkan tiga struktur teks dan tersusun secara sistematis dan sebagian kecil siswa hanya memunculkan dua atau satu struktur teks serta tidak tersusun secara sistematis. Kemampuan menulis teks laporan hasil observasi berdasarkan pengamatan langsung dari aspek mekanik siswa Kelas $\mathrm{X}$ SMA Negeri 1 Limboto Barat memperoleh nilai rata-rata 62 yang berada pada kategori cukup mampu. Hal ini dikarenakan beberapa siswa belum menguasai aturan penulisan, siswa terlihat masih bingung saat menentukan kata depan, kesalahan penempatan tanda baca, dan kesalahan dalam penggunaan huruf kapital pun masih banyak terjadi.

\section{DAFTAR PUSTAKA}

Akhadiah, Sabarti, dkk. (1998). Pembinaan Kemampuan Menulis Bahasa Indonesia. Jakarta: Erlangga.

Akhadiah, Sabarti, dkk. (2001). Pembinaan Kemampuan Menulis Bahasa Indonesia. Jakarta: Erlangga.

Dalman. (2014). Keterampilan Menulis. Jakarta: PT Raja Grafindo Persada.

Kemendikbud. (2013). Bahasa Indonesia: Wahana Pengetahuan (Buku Guru). Jakarta: Kementrian Pendidikan dan Kebudayaan.

Kemendikbud. (2013). Bahasa Indonesia: Wahana Pengetahuan (Buku Siswa). Jakarta: Kementrian Pendidikan dan Kebudayaan.

Kemendikbud. (2017). Bahasa Indonesia Ekspresi Diri dan Akademik: Buku Siswa SMA/MA SMK/MAK. Jakarta.

Kemendikbud. (2017). Bahasa Indonesia Ekspresi Diri dan Akademik: Buku Guru SMA/MA SMK/ MAK. Jakarta.

Moelong, Lexy J. (2009). Metodologi Penelitian Kualitatif. Bandung: Remaja Rosda Karya.

Nurhanifah. (2014). Jenis-jenis Teks. Yogyakarta : Gava Media.

Semi, M. Atar. (2007). Dasar-Dasar Keterampilan Menulis. Bandung: Angkasa.

Sugiyono, A. (2014). Metode Penelitian Pendidikan Pendekatan Kuantitatif, Kualitatif, dan $R \& D$. Bandung: Alfabeta.

Sugiyono. (2010). Metode Penelitian Administrasi. Cetakan ke-22. Bandung: CV Alfabeta. 
Warsita, Bambang. (2008). Teknologi Pembelajaran: Landasan \& Aplikasinya. Jakarta: Rineka Cipta.

Wijanarko, Agung Dwi. (2014). "Keefektifan Strategi Cooperative Integrated Reading And Composition (Circ) Dalam Pembelajaran Membaca Pemahaman Teks Laporan Hasil Observasi Pada Siswa Kelas Vii Smpn 6 Kota Magelang Sebagai Pelaksana Kurikulum 2013". Skripsi S1. Yogyakarta: FBS UNY. 